УДК 339.137.21

\title{
DEVELOPMENT MODEL ASSEMBLY CHAINS OF INOVATIONS' REPRODUCTION BY ENTERPRISES MILITARY \& INDUSTRIAL COMPLEX
}

\section{Larin Sergey Nicolaevich}

$\mathrm{PhD}$ in technical sciences, senior researcher

Akimkina Daria Alexandrovna

$\mathrm{PhD}$ in economics, senior researcher Central Economic \& Mathematic Institute RAS

\begin{abstract}
The relevance of this article is determined by the need to find effective ways to modernize the Russian economy in the context of the negative impact of sanctions restrictions. One of these areas may be the development of a model for assembling innovation reproduction chains by expanding the production of fundamentally new composite materials. Their use makes it possible to obtain significant competitive advantages for enterprises in the production chain, as well as for enterprises engaged in the production of new types of military equipment. The model for assembling innovation reproduction chains can be successfully implemented when modeling strategies for the innovative development of various sectors of the Russian defense industry. It opens up new opportunities for the production of modern military equipment using materials with new characteristics that were previously unavailable. At the present stage of modernization of the Russian economy, the use of new composite materials will make it possible to produce modern high-tech and science-intensive products in all sectors of the economy. Due to the presence of extreme properties and qualitatively new characteristics, composite materials are already used in almost all branches of the Russian defense industry.
\end{abstract}

Key words: Russian economy, sanctions restrictions, modernization, composite materials, innovation reproduction, competitive advantages 


\title{
РАЗВИТИЕ МОДЕЛИ СБОРКИ ЦЕПОЧЕК ВОСПРОИЗВОДСТВА ИННОВАЦИЙ ПРЕДПРИЯТИЯМИ РОССИЙСКОГО ОБОРОННО-ПРОМЫШЛЕННОГО КОМПЛЕКСА
}

\author{
Ларин Сергей Николаевич \\ кандидат технических наук, ведущий научный сотрудник \\ Акимкина Дария Александровна \\ кандидат экономических наук, старший научный сотрудник \\ Центральный экономико-математический институт РАН
}

Аннотация: актуальность данной статьи определяется необходимостью поиска эффективных направлений модернизации российской экономики в условиях негативного влияния санкционных ограничений. Одним из таких направлений может стать развитие модели сборки цепочек воспроизводства инноваций путем расширения масштабов производства принципиально новых композиционных материалов. Их применение позволяет получить существенные конкурентные преимущества для предприятий производственной цепочки, а также для предприятий, занятых производством новых образцов военной техники. Модель сборки цепочек воспроизводства инноваций может быть успешно реализована при моделировании стратегий инновационного развития различных отраслей российского ОПК. Она открывает новые возможности для выпуска современной военной техники с использованием материалов с новыми характеристиками, которые ранее были недоступны. На современном этапе модернизации экономики России применение новых композиционных материалов позволит производить современную высокотехнологичную и наукоёмкую продукции во всех отраслях экономики. Благодаря наличию экстремальных свойств и качественно новых характеристик композиционные материалы уже сейчас используются практически во всех отраслях российского ОПК.

Ключевые слова: российская экономика, санкционные ограничения, модернизация, композиционные материалы, воспроизводство инноваций, конкурентные преимущества 


\section{Foreword}

Leading branches of the industrial production in the developed countries of the world actively use composite materials for the production of a wide variety of products. The share of the use of these materials in the Russian economy is still several times inferior to foreign manufacturers. The leader in the use of composite materials is the aircraft industry. The share of composite materials in the products of this industry reaches $15 \%$. In other industries, this indicator is even lower.

Meanwhile, it seems obvious that in order to reduce the negative impact of sanctions restrictions, the Russian economy needs to promote research and development, as well as the production of high-tech products, at a faster pace. Today, the leading driver of the modernization of the Russian economy and its industrial production is the military-industrial complex (MIC). Due to the new characteristics, composite materials are used in most branches of the Russian defense industry. They are used for the production of modern bulletproof vests, as well as new models of military equipment in tank construction, naval shipbuilding, rocket engineering, aircraft construction and many others. On this basis, it can be argued that the development of a model for assembling innovation reproduction chains based on expanding the scale and application areas of new composite materials can become one of the significant competitive advantages of Russian defense industry enterprises. These advantages will allow the successful implementation of industry strategies for innovative development. The modern features of these processes will be disclosed in this article.

\section{Research purpose}

The purpose of this study is to identify ways to obtain competitive advantages for enterprises of the Russian defense industry by expanding the scale and scope of application of new composite materials.

\section{Research materials and methods}

The modernization of the Russian economy at the present stage contributes to the intensification of the production of high-tech and knowledge-intensive products. It should be based on the active introduction of innovative technologies and improving the quality of products in all industries. It is no coincidence that the Ministry of Industry and Trade of Russia has approved 2,200 technological directions for the development of the domestic economy and defined measures to stimulate leading industries and enterprises [1].

However, today the Russian economy is negatively affected by sanctions restrictions. They hinder the stable growth of production in the leading industries. 
The most significant of them can be considered limited funding for R \& D aimed at obtaining materials with fundamentally new characteristics. This factor contributes to maintaining the technological lag of Russian manufacturers of new-generation composite materials. Its consequence is an increase in purchases of necessary raw materials, resins and fibers abroad.

Another negative factor is the system of tenders for purchases. On the one hand, it clearly defines all the structural characteristics of materials, but on the other hand, it does not have the necessary flexibility to choose alternative solutions.

Also should be considered such negative factors as:

- lack of qualified specialists at the enterprises who have the necessary professional competencies, knowledge and experience in the production of composite materials;

- insufficiently effective interaction of large industrial enterprises engaged in the production of products made of composite materials with their manufacturers;

- lack of stimulation of the development of industrial production associated with the replacement of traditional materials with composite materials.

Another difficult problem is in the absence of effective mechanisms of technical regulation, Russian standards for the production of composite materials, as well as methods for conducting their tests. For example, only in 2015 in Russia, GOST was introduced for fiberglass. At the same time, it has been produced for more than two decades.

At the same time, now there are all conditions for the development of the production of composite materials. In the defense industry, these conditions are provided by the preserved scientific reserve, the implementation of industry strategies for innovative development, a clearer interaction of enterprises producing composite materials with large enterprises using them for the production of new models of military equipment. The current situation can be improved by applying the model of assembly of innovation reproduction chains (IRC), supported by concluded government contracts.

Qualitatively new characteristics of composite materials are created by using several constituent components-composites. They are based on the matrix of metal, polymer or ceramic, which is additionally reinforced with fillers from different types of fibers, crystals and particles [2]. Due to these characteristics, composite materials are successfully used in the aviation, auto, ship and rocket industries for the production of military and civilian products. Elements of devices and equipment 
made on the basis of composite materials are suitable for operation in aggressive environments, at high and low temperatures: in space, at nuclear reactors.

The main types of composite materials include metal composite materials, ceramic composite materials, organic plastics, and fabric based laminates. However, polymer-composite materials (PCM) have become the most widely used ones. There are filled with various polymeric substances, and a wide range of properties of PCM opens up endless opportunities for their application in various sectors of the economy. Modern practice shows that PCM is most effectively used in high-tech industries. So, a modern aircraft can no longer be created without the use of PCM. In advanced aircraft models, the share of PCM is more than $60 \%$. The main feature of the PCM is the possibility of obtaining a certain set of characteristics by combining various matrices and reinforcing elements. In other words, today it is possible to produce PCM with predetermined properties for their application in specific sectors of the economy [2].

Today, three methods are used for the production of PCM and products made from them. The first of them - the vacuum infusion technology-allows you to produce products of a sufficiently large size. However, a significant disadvantage of this technology is the high cost of the materials used. The second method of production of PCM - molding with resin supply (RTM - Resin Transfer Molding), on the contrary, has limited use in the production of too large products. For this reason, it is used for the production of medium-sized products, from which the entire structure is assembled. The third method-autoclave molding-allows you to get a product with improved properties with significant savings of all components. But its disadvantages are the significant cost of equipment and the cost of products with limited dimensions, as well as the duration of their manufacture. It is obvious that the use of these methods is possible only in the conditions of stationary high-tech production in the presence of highly qualified specialists [2].

The use of PCM for the production of new models of military equipment combines several technological processes. First, conventional and structural materials are selected in a certain sequence. During production, they are converted into PCM by one or another technology and are used to assemble a specific product.

\section{Results and discussion}

A number of enterprises produce various types of PCM for the needs of the branches of the Russian defense industry. In some of them, the share of foreign components and equipment manufactured using PCM exceeded 90\% in 2016. The development of the IRC assembly model by expanding the production of 
fundamentally new composite materials will significantly reduce this indicator. In addition, the IRC assembly model will help improve interaction between all participants in the production of new models of military equipment, starting from manufacturers of composite materials and ending with the assembly of finished products.

The first results are already being viewed today. At industrial enterprises of the defense industry, such as the Sredne-Nevsky Shipbuilding Plant, Steklonit, Research Institute of Polymers, Dugalak, Elektroizolit and a number of others, R \& D is carried out for the development of fiberglass, metal foams, binders of vinyl ether resins, which were previously only purchased by import [3].

Other enterprises have successfully mastered the production of PCM consoles for small and medium-sized vessels. Technologies for the production of three-layer PCM panels for the manufacture of bulkhead sections, decks and superstructures of surface ships have been implemented. The development of technology for the production of elements of ship hulls from PCM is being completed. In 2017, a catalog of products that it is advisable to produce from PCM for the shipbuilding industry was created, and the production of experimental batches of such products was introduced at USC enterprises. The obtained results gave a new impetus to the use of modern PCM in Russian shipbuilding.

Today, the annual commissioning of warships, the hulls of which are completely made of PCM, is becoming common for the Russian Navy. The first unique minesweeper «Alexander Obukhov» with a total displacement of 890 tons was accepted into the Navy in 2016. The main feature of the hull of this ship is that it is completely made of PCM in the form of monolithic fiberglass. The use of this material made it possible to increase the strength of the hull compared to the hulls of other ships made of ordinary materials. In addition to increasing the strength of ship hulls, the use of PCM in the shipbuilding industry provides a significant reduction in their total weight. This contributes to an increase in the speed of movement by $10-20 \%$ without any modernization of the engines of the running gear and the mass of the payload in the form of additional units of military equipment and kits for weapons systems [4]. The successful development of radio-absorbing PCM should also be noted, which are used for the production of corvettes of projects 20380 and 20385.

At a number of enterprises of the Rostech Corporation, mass production of PCM products for the Angara and Proton launch vehicles is currently being carried out. At the same time, up to $40 \%$ of the parts for such products are made on the basis 
of PCM. This made it possible to reduce the weight of the launch vehicles themselves by $12 \%$ [4].

Almost all elements of sound-absorbing panels of aircraft engines of PAK DA, PAK FA and IL-112 aircraft are produced at domestic enterprises using modern PCM. This made it possible to reduce the weight of aircraft without equipment by $20-30 \%$, to significantly reduce the time and total cost of their production [3].

Currently, the share of PCM applications in the aircraft industry is steadily increasing. If in the $80 \mathrm{~s}$ of the last century, products made of PCM accounted for $10-15 \%$ of the weight of the aircraft, then in modern mainline aircraft this figure exceeds $60 \%$. The structures of the center section, fuselage, wing and tail are made of PCM. For the newest Russian aircraft MS-21, the Aerocomposite plant in Ulyanovsk has launched mass production of a PCM wing structure [5]. In the aircraft industry, $\mathrm{R} \& \mathrm{D}$ is being carried out to develop the latest technologies for the production of light radio-absorbing PCM based on nanocarbon compounds.

Today, the PCM is the basis for the development and creation of devices with increased stealth properties, which include unmanned aerial vehicles (UAVs). The use of PCM in the structural parts of UAVs makes it much more difficult to detect them at medium and long distances.

Thanks to the successful use of PCM in the aircraft industry, Russia is among the leading countries in the world for the production of modern military aircraft. For example, on the fifth-generation multifunctional fighter T-50 (PAK FA), the fuselage is completely made of modern radio-absorbing PCM, and the share of PCM is almost $25 \%$ of the total weight of the aircraft, excluding ammunition. In addition, due to the use of PCM, the total number of parts used for assembling the aircraft was significantly reduced. Similar radio-absorbing PCM are used in the production of the fuselages of MiG-29K/KUB and Mig-35 fighters. The MIG Corporation has launched a special production of high-strength carbon fiber parts, which uses materials of only Russian origin, including carbon fiber thread [4].

Different types of armor protection made from PCM have appeared and are successfully used. These include hybrid interlayer polymer-metal and polymerceramic materials, as well as modern nanopolymer and electroactive polymer materials, from which a combined armor protection is formed. Having high impactresistant and low weight characteristics, PCM is widely used in the structures of the outer skin and superstructures of warships. So, for example, the Russian corvettes of the «Steregoushtchy» type have a superstructure made entirely of lightweight PCM. 
The use of armor protection from PCM for various purposes is a recognized trend in the development of the world tank building. The use of PCM armor protection made it possible to replace traditional armor made of durable steel and significantly increase the protection of the tank and its crew from cumulative, kinetic and other projectiles.

In the production of military helicopters, ceramic-plastic armor provides protection for the cockpit in the 360-degree firing sector. This effect was achieved by the joint use of this type of armor protection in the «protector» of the cabin itself and booking the backs of the crew seats. Currently, in the production of modern helicopters, individual elements or the entire body are made from PCM. The production of all-composite carbon fiber blades for Mi-38, Mi-35M, Mi-28NM helicopters has made them more reliable by increasing the strength of the blades and increasing their motor life. The lightening of the weight of the helicopters led to an increase in their cruising and maximum speed by $10-15 \%$ [4].

The fifth generation of Russian submarines has many elements, made of PCM. This is a multi-layer composite hull, control rudders (fore and aft), stabilizers, enclosing structures of the wheelhouse, propeller blades, shafts of main engines, etc. Its production started in 2020.

\section{Conclusions}

Results, obtained in the course of the research, allow to formulate following conclusions.

1. The growth in the production of various PCM opens up opportunities for creating new models of military equipment with fundamentally high-quality characteristics. The introduction of the IRC assembly model into the activities of enterprises of the Russian defense industry will increase the production of modern PCM, create new technologies for their use for the manufacture of competitive samples of military equipment, will entail an increase in the share of defense industry enterprises in the international market.

2. With the use of the IRC assembly model, prospects for the implementation of new competitive advantages by enterprises of the Russian defense industry are opened necessary prerequisites are created for the use of the latest PCM in civil industries.

3. The leading enterprises of the Russian defense industry are currently implementing a significant number of projects using the IRC assembly model. However, their success depends on the implementation of a consistent and balanced state industrial policy in the field of finance, planning of the state defense order and 
balanced protectionism of all interested participants, starting from state structures and ending with specific manufacturers of composite materials and new models of military equipment.

\section{Acknowledgments}

The work has been performed with the financial support of the Russian Foundation of Fundamental Studies, project № 20-010-00169a.

\section{List of literature}

1. Materials from the official site of the Ministry of Industry and Trade of the Russian Federation [Electronic resource]. URL - https://minpromtorg.gov.ru/.

2. Composite materials: what is it, features, production and application [Electronic resource]. URL - https://fb.ru/article/264869/kompozitnyie-materialyichto-eto-takoe-svoystva-proizvodstvo-i-primenenie.

3. Zazimko V. Application of composite materials as a driver of MIC branches // New defense order: strategies, 2017, № 2 (44).

4. Materials from the official site of Rostech corporation [Electronic resource]. URL - https://rostec.ru.

5. Larin S.N., Noack N.V., Sokolov N.A. Competitive advantages of the Russian military \& industrial complex and its implementation in import substitution strategies // Economics and business: theory and practice, 2019, № 7. P. 97-103. 